\title{
Application of Contemporary Magnifying Methods in the Diagnostics of Occlusal Carious Lesions on First Permanent Molars in Children
}

\author{
Maya Rashkova, Ralitsa Bogovska-Gigova, Hristina Tankova, Natalia Gateva, Nadezhda Mitova, \\ Krasimir Hristov \\ Department of Pediatric Dental Medicine, Faculty of Dental Medicine, Medical University of Sofia, Sofia, Bulgaria
}

Corresponding author: Nadezhda Mitova, Department of Pediatric Dental Medicine, Faculty of Dental Medicine, Medical University of Sofia, 1 St Georgi Sofiiski Blvd., 1431 Sofia, Bulgaria; E-mail: nadia_bm@abv.bg; Tel.: + 359886216886

Received: 29 Oct 2019 Accepted: 20 Dec 2019 Published: 30 Sep 2020

Citation: Rashkova M, Bogovska-Gigova R, Tankova H, Gateva N, Mitova N, Hristov K. Application of contemporary magnifying methods in the diagnostics of occlusal carious lesions on first permanent molars in children. Folia Med (Plovdiv) 2020;62(3):585-91. doi: 10.3897/folmed.62.e47751.

\begin{abstract}
Introduction: Dental operating microscopes (DOM) enable dentists to examine, with the aid of magnification and photodocumentation in clinical conditions, the occlusal anatomy of newly erupted permanent molars and to detect any early carious lesions more precisely.
\end{abstract}

Aim: To determine the advantages of magnifying technology in detecting early occlusal carious lesions in newly erupted permanent first molars.

Materials and methods: We examined 176 first molars of 44 children divided into two age groups: 7-8 and 9-10 years. The surfaces of each of the teeth were examined after they were cleaned with a brush without paste. The diagnoses were first made using only illumination and a clinical examination. These were followed by a visual examination of the occlusal surface using a DOM at $\times 8$ magnification. A photo of the occlusal surface was then taken with a camera at the respective magnification for the purposes of photodocumentation.

Results: This study demonstrated that dental operating microscopes increased by $7 \%$ the rate of successful detection of early caries lesions on the occlusal surfaces. There was also a significant increase of the number of diagnosed cavitated caries in the dentine in comparison with those detected with naked eye. Using DOMs in pediatric dentistry facilitates the more detailed and precise diagnosing of early stage carious lesions and/or cavitations in the fissures.

Conclusion: The use of a DOM facilitates differential diagnosing between deep fissures and early carious lesions, which is a key point in the assessment of occlusal surfaces of newly erupted permanent molars, necessary for their preventative sealing and micro-invasive treatment.

\section{Keywords}

dental operating microscope, early diagnosis, occlusal caries

\section{INTRODUCTION}

The use of dental operating microscope (DOM) is an innovative method in dental practice. It enables the deve- lopment of new diagnostic and treatment strategies in dentistry, with clinical application in specialized dental interventions. ${ }^{1-6}$

The preventative approach, accompanying the dental procedures in children, is the main strategy of micro-inva-

Copyright by authors. This is an open access article distributed under the terms of the Creative Commons Attribution License (CC-BY 4.0), 
sive treatment. A precise diagnosis is a prerequisite of correct clinical decision about the treatment method and its successful outcome. This diagnosis requires good visibility and illumination of the operative field. At the same time, the possibilities the digital magnifying technologies offer are important, especially in the contemporary diagnosis of initial carious lesions. The dental operating microscope enables the examination of the occlusal anatomy of newly erupted permanent molars and a more accurate diagnosis of initial carious lesions with the aid of magnification and photo documentation in clinical settings. DOM may also be used for motivation and education of young patients. In the context of minimally invasive approach, which is the standard in pediatric dental medicine, its use in children has not yet been thoroughly studied. ${ }^{1-7}$

The occlusal surfaces of the permanent teeth are at the highest risk for the development of carious lesions right after eruption. ${ }^{8}$ The main reasons for this are the complex macro morphology of the system of pits, grooves and fissures and the eruption stage related to the role of the tooth in masticatory function. They are considered as biological determinants for the development of occlusal caries due to their relation with the formation, distribution and accumulation of dental plaque. ${ }^{9}$

The diagnosis of any initial carious lesions on the occlusal surface is a serious challenge due to its anatomical features, which prevent a direct assessment of the dental structures. Right after the tooth's eruption the enamel at the bottom of the fissure is very thin or, in other areas, is completely missing. This makes it possible for the lesion to start directly in the dentine. Failure to comply with the specificity of the occlusal relief and the lack of accurate diagnosis of the initial carious lesions pose the risk of unnecessary removal of dental structures. ${ }^{7,10-12}$ Once applied, the operative treatment involves the tooth in restorative cycle for the rest of the patient's life. ${ }^{13}$

\section{AIM}

The aim of this study was to determine the advantages of magnifying technology in diagnosing early occlusal carious lesions in newly erupted permanent first molars.

In order to achieve this, the following tasks were set:

1. To register the oral hygiene and dental status of the children, participating in the study.
2. Making a comparative characteristic of the carious lesions of the first permanent molars with and without a dental operating microscope.

\section{MATERIALS AND METHODS}

The study included 44 healthy children divided into two age groups (7-8 and 9-10 years old); their dental and oral hygiene status was taken and recorded. A detailed comparative study with and without magnification of the occlusal surface was performed on 176 first permanent molars. The children were included in the study after explaining the aims of the study to their parents/guardians and obtaining their written consent. An approval from KENIMUS - the Ethics Committee of the Medical University of Sofia was also obtained (No 24/07.12.2018).

The oral health status of the children was recorded in an oral health assessment card. The carious lesions we detected were classified according to prof. Peneva's diagnostic scale (Table 1). ${ }^{14,15}$

The DMFT index was used to assess the total caries prevalence in the children with permanent dentition. For the children with mixed dentition the $\operatorname{dmf}(\mathrm{t})$ index was also assessed. The clinical examination includes:

- Taking the dental status using the $\operatorname{DMF}(\mathrm{T})$ and the dm$\mathrm{f}(\mathrm{t})$ indexes;

- The oral hygiene index - OHIs (Green-Vermillion) assessment;

- Examination of the occlusal surfaces of the first four permanent molars, using the following criteria:

- caries prevalence, according to the diagnostic scale of prof. Peneva; ${ }^{14,15}$

- the number of carious lesions on one occlusal surface one, two or three lesions;

- registration of the carious lesions in pits or in pits and adjacent fissures;

- visual characteristics of the carious lesions in pits and fissures - change in enamel translucency, staining, cavitation in the enamel, suspected cavitation in the dentine, visible cavitation in the dentine, characteristics of the cavity borders.

The diagnosis of each occlusal lesion was made after cleaning the tooth with a brush without paste. The initial diagnosis was carried out only with illumination and a clinical examination. Any registered findings regarding the

Table 1. Diagnostic scale of carious lesions (Peneva M). ${ }^{14,15}$

\begin{tabular}{ll}
\hline $\begin{array}{l}\text { Lesion } \\
\text { type }\end{array}$ & Visual criteria \\
\hline D0 & No changes, healthy enamel. \\
D1a & The earliest stage of enamel lesion, loss of translucency of the enamel, visible under plaque and after drying. \\
D1b & White enamel lesion, visible after drying. \\
D2 & White, yellow or brown enamel lesion, visible without drying, combined with one or two small cavitations in the enamel. \\
D3a & Cavitated dentine lesion, located in the outer half of the dentine. \\
D3b & Cavitated lesion in the dentine, located in the inner half of the dentine. \\
\hline
\end{tabular}


conditions of the occlusal surfaces of all the teeth included in the study were recorded in the patient's medical card.

After that a visual examination of the occlusal surface was performed using a DOM (Semorr DOM 3000E) with $\times 8$ magnification and the result was recorded in the patient's card. The occlusal surface of each molar was photographed with Nikon D5300 DSLR, mounted on the DOM. The obtained data were statistically analyzed with SPSS (version 19, SPSS Inc., USA) with 95\% confidence interval $(p<0.05)$.

\section{RESULTS}

\section{Oral hygiene and caries prevalence of the children}

\section{Oral hygiene}

The mean values of the oral hygiene index (OHI-S) according to the age of the children included in the study are shown in Table 2.

Table 2. Average values of OHI-S in 7-10-year-old children

\begin{tabular}{|c|c|c|c|}
\hline \multirow{2}{*}{ Children groups } & \multirow{2}{*}{$\mathbf{N}$} & OHI-GV & \multirow{2}{*}{ Ind T-test } \\
\hline & & Mean \pm SD & \\
\hline 7-8 years old & 24 & $1.21 \pm 0.37$ & \multirow{3}{*}{$\mathrm{t}=0.892, \mathrm{p}=0.136$} \\
\hline $9-10$ years old & 20 & $1.19 \pm 0.41$ & \\
\hline Average & 44 & $1.20 \pm 0.39$ & \\
\hline
\end{tabular}

The mean values of the OHI-S index are slightly above one, with no significant difference between the compared age groups $(p>0.05)$. The results show that the oral hygiene of the children is satisfactory.

\section{Caries prevalence of the patients}

Table 3 shows the distribution of the subjects from each age group according to the mean value of the $\operatorname{DMF}(\mathrm{T})$ and
Table 3. Mean values of DMF $(\mathrm{T})$ and $\mathrm{dmf}(\mathrm{t})$ on visual observation

\begin{tabular}{llll}
\hline Children groups & $\mathbf{N}$ & $\begin{array}{l}\operatorname{DMF}(\mathbf{T}) \text { and } \\
\mathbf{d m f}(\mathbf{t})\end{array}$ & Ind T-test \\
\cline { 2 - 3 } & & $\operatorname{Mean} \pm \mathbf{S D}$ & \\
\hline 7-8 years old & 24 & $11.79 \pm 5.38$ & \\
9-10 years old & 20 & $10.80 \pm 6.85$ & $\mathrm{t}=0.538, \mathrm{p}=0.593$ \\
Total & 44 & $11.29 \pm 6.11$ & \\
\hline
\end{tabular}

$\operatorname{dmf}(\mathrm{t})$ indexes.

The caries prevalence $(\mathrm{DMF}(\mathrm{T})+\operatorname{dmf}(\mathrm{t}))$ of the patients shows that they have on average between 10 and 12 teeth affected by caries. No significant difference is observed between the children from each age group ( $p>0.05)$ (Table 3 ). The high average values of the index place the children at a high risk of developing caries.

\section{Clinical characteristics of the occlusal surfaces of the first permanent molars without magnification}

The data from the clinical status of the occlusal surfaces of the first molars included in the study is presented in Table 4. The teeth are grouped according to their localization in the dentition (16 - maxillary right first molars, 26 - maxillary left first molars, 36 - mandibular left first molars, 46 - mandibular right first molars).

The data indicate that $2 / 3$ of the first permanent molars have carious lesions $(p<0.05)$ (Table 4$)$. The relative portion of the carious teeth in relation to the tooth groups is approximately similar - from $12.5 \%$ to $17.6 \%$. More than a quarter of the molars have healthy occlusal surfaces $(29.6$ $\%)$, while the portion of the teeth with sealants and restorations is about $10 \%$ and distributed equally.

\section{Characteristics of the carious lesions of the first permanent molars, with and without magnification}

Table 4. Data from the clinical examination of the first permanent molars examined without magnification

\begin{tabular}{|c|c|c|c|c|c|c|c|c|}
\hline \multirow{2}{*}{ Tooth } & \multicolumn{2}{|c|}{ No caries (1) } & \multicolumn{2}{|c|}{ With caries (2) } & \multicolumn{2}{|c|}{ With sealant (3) } & \multicolumn{2}{|c|}{ With restoration (4) } \\
\hline & $\mathbf{N}$ & $\% \pm s p$ & $\mathbf{N}$ & $\% \pm s p$ & $\mathbf{N}$ & $\% \pm s p$ & $\mathbf{N}$ & $\% \pm \mathrm{sp}$ \\
\hline 16 & 18 & $10.2 \pm 2.28$ & 22 & $12.5 \pm 2.49$ & 2 & $1.1 \pm 0.80$ & 2 & $1.1 \pm 0.80$ \\
\hline 26 & 14 & $8.0 \pm 2.04$ & 27 & $15.3 \pm 2.78$ & 0 & 0 & 3 & $1.7 \pm 0.98$ \\
\hline 36 & 11 & $6.3 \pm 1.82$ & 27 & $15.3 \pm 2.72$ & 3 & $1.7 \pm 0.98$ & 2 & $1.1 \pm 0.80$ \\
\hline 46 & 9 & $5.1 \pm 1.66$ & 31 & $17.6 \pm 2.87$ & 2 & $1.1 \pm 0.80$ & 3 & $1.7 \pm 0.98$ \\
\hline \multirow[t]{3}{*}{ Total } & 52 & $29.6 \pm 3.44$ & 107 & $60.8 \pm 3.68$ & 7 & $4.0 \pm 1.47$ & 10 & $5.7 \pm 1.74$ \\
\hline & \multirow{2}{*}{\multicolumn{2}{|c|}{$\begin{array}{l}\mathrm{t}(1,2)=6.200, p<0.05 \\
\mathrm{t}(2,3)=14.330, p<0.05\end{array}$}} & \multirow{2}{*}{\multicolumn{2}{|c|}{$\begin{array}{l}\mathrm{t}(1,3)=6.830, \mathrm{p}<0.05 \\
\mathrm{t}(2,4)=13.530, \mathrm{p}<0.05\end{array}$}} & \multicolumn{2}{|c|}{$\mathrm{t}(1,4)=6.190, \mathrm{p}<0.05$} & & \\
\hline & & & & & \multicolumn{2}{|c|}{$\mathrm{t}(3,4)=0.750, p>0.05$} & & \\
\hline
\end{tabular}

Pearson Chi Square $=8.116 \quad$ Sig $=0.523$ 


\section{Caries prevalence according to the diagnostic scale $^{14,15}$}

The assessment of the severity of the occlusal carious lesions is presented in Table 5.

Lesions at stage D1a or D1b were not found on the examined occlusal surfaces. This fact supports the standpoint that the clinical features of the earliest changes in the enamel are mainly visible on smooth surfaces. Most of the lesions were in stage D2 - enamel lesion, visible without drying, mainly with a brownish colour (Fig. 1). These lesions were $92.52 \%$ of all without magnification, whereas with magnification the percentage was $78.26(p<0.05)$. This significant difference could be explained by the greater precision in the examination with magnification, where parts of the enamel lesions are registered as lesions in the dentine (Table 5).

The observed carious lesions without magnification were about $8 \%$, evenly distributed between more superficial and deeper part of the dentine. Using DOM the carious lesions in the outer half of the dentine were 4 times more than these in the inner half $(p<0.05)$. Apparently, this difference is due to the fact that lesions visible like enamel lesions with naked eye are registered like dentine lesions with the use of DOM (Fig. 2).

\section{Number of the carious lesions on the occlusal surface, examined with magnification}

The number of carious lesions on the occlusal surface is presented in Table 6.

The results show that $3 / 4$ of the carious first permanent molars have a single lesion on the occlusal surface $(p<0.5)$ (Table 6). Eighty of the lesions are located in separate areas of the fissure, while eight affect the entire occlusal surface (Table 7). The remaining $1 / 4$ of the examined teeth have 2 or 3 carious lesions on the occlusal surface. The distribution of lesions remains relatively uniform in all the examined groups of molars, which shows that the difference in the morphology of upper and lower molars is not significant for the number of the carious lesions $(p>0.05)$. These lesions are in an early stage of development and they have not encompassed the entire fissure. Each of them has a diffe-

Table 5. Number of the carious lesions according to the diagnostic scale ${ }^{14,15}$

\begin{tabular}{llllll}
\hline \multirow{2}{*}{ Diagnostic scale } & \multicolumn{2}{l}{ Observed without magnification } & \multicolumn{2}{l}{ Observed with magnification } & \multirow{2}{*}{ Ind T-test } \\
\hline D2 & $\mathbf{n}$ & $\mathbf{\%} \pm \mathbf{s p}$ & $\mathbf{n}$ & $\mathbf{\%} \pm \mathbf{s p}$ & $\mathrm{t}=3.09, p<0.05$ \\
D3a & 99 & $92.52 \pm 2.54$ & 90 & $78.26 \pm 3.85$ & $\mathrm{t}=3.59, p<0.05$ \\
D3b & 4 & $3.74 \pm 1.83$ & 21 & $18.26 \pm 3.60$ & $\mathrm{t}=0.10, p>0.05$ \\
Total & 4 & $3.74 \pm 1.83$ & 4 & $3.48 \pm 1.71$ & \\
\hline
\end{tabular}

Table 6. Number of carious lesions on the occlusal surface, examined with magnification

\begin{tabular}{lllllllll}
\hline \multirow{2}{*}{ Tooth } & \multicolumn{2}{l}{ One lesion (1) } & \multicolumn{2}{c}{ Two lesions (2) } & \multicolumn{2}{c}{ Three lesions (3) } & \multicolumn{2}{c}{ Total } \\
\cline { 2 - 8 } & $\mathbf{N}$ & $\mathbf{\%} \pm \mathbf{s p}$ & $\mathbf{N}$ & $\mathbf{\%} \pm \mathbf{s p}$ & $\mathbf{N}$ & $\mathbf{\%} \pm \mathbf{s p}$ & $\mathbf{N}$ & $\%$ \\
\hline 16 & 22 & $84.1 \pm 7.08$ & 4 & $15.5 \pm 7.08$ & 0 & 0 & 26 & $100 \%$ \\
26 & 23 & $79.3 \pm 7.52$ & 6 & $20.7 \pm 7.52$ & 0 & 0 & 29 & $100 \%$ \\
36 & 21 & $72.4 \pm 8.30$ & 6 & $20.7 \pm 7.52$ & 2 & $6.9 \pm 4.71$ & 29 & $100 \%$ \\
46 & 22 & $71.0 \pm 8.15$ & 9 & $29.0 \pm 8.15$ & 0 & 0 & 31 & $100 \%$ \\
Total & 88 & $76.5 \pm 3.95$ & 25 & $21.7 \pm 3.85$ & 2 & $1.74 \pm 1.22$ & 115 & $100 \%$ \\
\hline & $\mathrm{t}(1,2)=9.930, \mathrm{p}<0.05$ & \multicolumn{2}{l}{$\mathrm{t}(1,3)=18.080, \mathrm{p}<0.05$} & $\mathrm{t}(2,3)=4.960, \mathrm{p}<0.05$ & &
\end{tabular}

Pearson Chi Square $=7.643 ;$ Sig $=0.265$

Table 7. Localization of the carious lesions, with and without magnification

\begin{tabular}{|c|c|c|c|c|c|}
\hline & \multicolumn{2}{|c|}{ Assessment without DOM } & \multicolumn{2}{|c|}{ Assessment with DOM } & \multirow{2}{*}{ Ind T-test } \\
\hline & $\mathbf{N}$ & $\% \pm s p$ & $\mathbf{n}$ & $\% \pm s p$ & \\
\hline Caries of the pit & 20 & $18.69 \pm 3.77$ & 5 & $4.35 \pm 2.84$ & $\mathrm{t}=3.40, p<0.05$ \\
\hline $\begin{array}{l}\text { Caries of the pit and the adjacent fissure/ } \\
\text { fissures }\end{array}$ & 79 & $73.83 \pm 4.25$ & 102 & $88.70 \pm 2.95$ & $\mathrm{t}=2.87, p<0.05$ \\
\hline Caries of the whole occlusal surface & 8 & $7.48 \pm 2.54$ & 8 & $6.96 \pm 2.37$ & $\mathrm{t}=0.15, p>0.05$ \\
\hline Total & 107 & $100 \%$ & 115 & $100 \%$ & \\
\hline
\end{tabular}



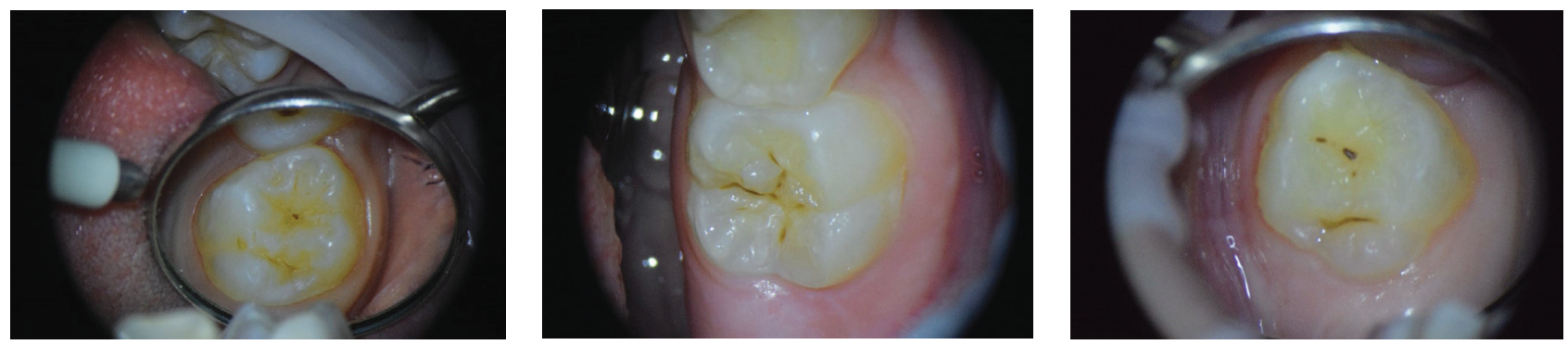

Figure 1. Permanent first molars with initial enamel carious lesions.

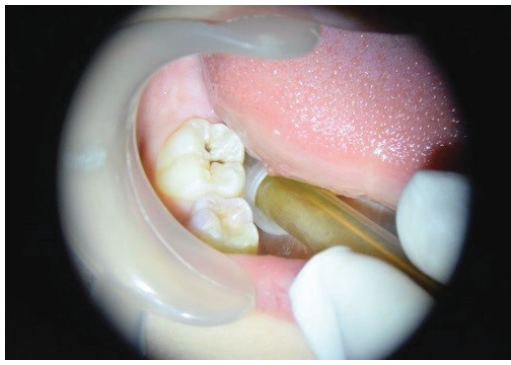

Observation without magnification

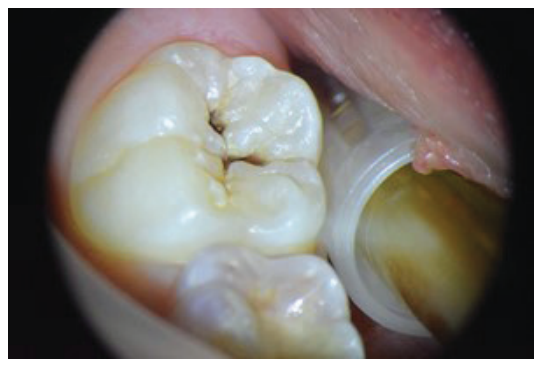

Observation with DOM

Figure 2. Right lower permanent first molar with dentine carious lesion.

rent severity and requires a differentiated approach in the treatment.

\section{Number of the carious lesion in pit and fissures, with and without magnification}

The findings observed on the occlusal surfaces, examined with and without DOM are presented in Table 7.

In the study without DOM, 107 carious lesions were registered, while with the application of magnification the carious lesions were 115 . The difference of these 8 lesions represents $7 \%$ of the carious molars. On the other hand, another 8 lesions, which are located on the whole occlusal surface, are clearly visible with and without magnification.

The remaining carious lesion observed without DOM are distributed as follows: 20 only in pits and 79 in pits and the adjacent fissure/fissures. When observed with a DOM, 5 of the lesions are located only in the fossa and 102 in the fossa and adjacent fissures $(\mathrm{p}<0.05)$.

These results indicate that most probably 8 carious lesions, which are visible only with the usage of DOM, fell into the group of lesions in pits and adjacent fissures. The magnification provides more precise information about the periphery of the early cars lesions, proved by the fact that the lesions located in pits and adjacent fissures are definitely more than these located only in pits $(\mathrm{p}<0.05)$.

\section{DISCUSSION}

The high caries prevalence of the first permanent molars, right after eruption, is often due to the complex morpho- logy of their occlusal surfaces, comprised of a diverse and highly retentive relief. Areas with thin to missing enamel can be observed in the deepest points of the fissures, sometimes reaching directly to the enamel-dentin junction. The fissures of the mandibular molars are the deepest and most complex. They are the least mineralized areas of the permanent molars, right after eruption. ${ }^{12}$

Due to the complex anatomy of this occlusal area, as well as the generally narrow pit/fissure entry, which impairs direct observation, more sensitive contemporary methods are necessary for assessing the health of the dental structures and the diagnosing of initial carious changes. ${ }^{4,16}$ The early detection of carious lesion is crucial for limiting the operative treatment. Pain and anxiety in children can be avoided, as well as any unnecessary removal of dental structures. ${ }^{17-19}$

The micro-invasive approach in dental medicine makes it possible to apply various preventative strategies and treatment methods in the earliest stages of the carious lesions, including early diagnosis. The visual-tactile method is the traditional and most frequently used method for identifying early carious lesions. It is necessary however to develop new and more sensitive methods to facilitate the diagnosing of early occlusal lesions. ${ }^{20,21}$ The results of this study proved that the traditional visual approach is insufficient on its own and there is a risk for early occlusal carious lesions to be missed (Table 5) which prevents the ability for their progression to be arrested early on and preventive treatment to be applied.

Several new technologies have been introduced to aid the clinician in the diagnosis of early carious lesions, especially those found in the fissures that are harder to exami- 
ne through direct observation, but there is not much data regarding the advantages of the DOM in pediatric dental medicine. ${ }^{22-24}$

A group of authors conducted a study regarding the role of magnification in the early diagnosis of carious lesions by comparing the clinical diagnoses of 299 occlusal surfaces, examined directly and with the aid of a DOM. They found that the diagnoses differed most frequently for teeth that were assessed as healthy during direct observation, but were found to have a carious lesion, when observed under magnification. ${ }^{25}$

The results from the aforementioned study match the results of this study (Tables 5,7 ). This study shows that the dental operating microscope increases the successful diagnosing of early caries lesions on the occlusal surfaces by $7 \%$. The use of a DOM in pediatric dentistry facilitates a more detailed and precise diagnosis of early stage carious lesions and/or cavitation in the fissures.

A study has compared the data of registered early carious lesions when using magnifying glasses $(\times 1.8)$ and a dental operating microscope $(\times 3.4)$. The results yet again confirm the advantage of the DOM $(\times 3.4)$ magnification in facilitating a more precise diagnosis. ${ }^{26}$ The results are similar to those of this study which found that using a DOM with $(\times 8)$ magnification the diagnosis of initial carious lesions was more precise than in a direct observation.

According to other authors, the effectiveness of the DOM is statistically similar to that of the direct observation method, but regardless of that they consider that the accuracy of diagnostic methods using magnification must be more thoroughly studied. ${ }^{27}$

Another advantage of magnification in diagnosing occlusal caries with a DOM can be considered in this study. There is a significant increase in the number of diagnosed cavitated caries in the dentine, when compared to those registered with the naked eye. With a DOM the initial clinical symptoms of enamel undermining, which loses its transparency at the periphery of the lesion were able to be observed. Micro-cracks in that same enamel, which are invisible to the naked eye, were also observed.

The use of a DOM facilitates differential diagnosing between deep fissures and early carious lesions, which is a key point in the assessment of occlusal surfaces of newly erupted permanent molars, in order for their preventative sealing and micro-invasive treatment. In this way the newly erupted teeth will be spared an early and unnecessary removal of dental structures.

\section{CONCLUSIONS}

1. When using magnification, the number of early carious lesions on the occlusal surfaces increases by $7 \%$; 2. The affected occlusal fissures, adjacent to the carious pits, are registered better when using magnification; 3. The use of magnification facilitates the more detailed and precise diagnosis of early cavitation in the fissures, which initially is harder to detect through direct observation;

4. The use of a DOM allows more accurate differential diagnosis between a deep fissure and early occlusal carious lesions in recently erupted permanent molars.

\section{REFERENCES}

1. Bjørndal L. Indirect pulp therapy and stepwise excavation. JOE 2008; 34(7),Supplement: S29-S33.

2. Kidd EA, van Amerongen JP, van Amerongen WE. The role of operative treatment in caries control. In: Fejerskov O, Kidd E, editors. Dental Caries: The disease and its clinical management, 2nd ed. Oxford: Blackwell Munksgaard; 2008, 356-65.

3. Splieth $\mathrm{CH}$. Revolutions in pediatric dentistry. 1st ed. Quintessenz Verlags-GmbH, 2011: 214.

4. Schwendicke F, Jäger AM, Paris S, et al. Treating pit-and-fissure caries: a systematic review and network meta-analysis. J Dent Res 2015; 94(4): 522-33.

5. Carlos Murgel. Microdentistry: concepts, methods, and clinical incorporation. Int J MicroDent 2010; 2(1): 56-63.

6. Fanibunda U, Meshram G, Warhadpande M. Evolutionary perspectives on the dental operating microscope: a macro revolution at the micro level. Int J MicroDent 2010; 2(1): 15-9.

7. Glenn A. van As. Digital documentation with the dental operating microscope: What you see is what you get. The International Journal of MicroDentistry 2009; 1: 30-42.

8. Marthaler TM. Changes in dental caries 1095-2003. Caries Res 2004; 38: 173-181.

9. Carvalho JC. Caries process on occlusal surfaces: evolving evidence and understanding. Caries Res 2014; 48: 339-46.

10. Peneva M. [Dental caries in the XXI century.] East-West Sofia 2008: 234 [In Bulgarian].

11. Schwendicke F, Frencken J, Innes N, editors. Caries excavation: evolution of treating cavitated carious lesions. KARGER 2018:176.

12. Waggoner WF. Managing occlusal surfaces of young permanent molars. Journal of the American Dental Association 1991; 122(11): 72-6.

13. Rashkova M. Microinvasive approach in the treatment of caries in children - modern aspects. Problems of dental medicine 2013; 39 (2): 70-81.

14. Peneva M, Kabakchieva R, Rashkova M, et al. Clinic of pediatric dentistry. Sofia: Bedemot; 2018; 118-43 [In Bulgarian].

15. Peneva M. Activity of the caries process. Journal of IMAB Annual Proceeding (Scientific Papers) 2008 book 2.

16. Lussi A, Francescut P. Performance of conventional and new methods for the detection of occlusal caries in deciduous teeth. Caries Res 2003; 37: 2-7.

17. Innes N, Frencken J, Bjørndal L, et al. Managing carious lesions: consensus recommendations on terminology. Adv Dent Res 2016; 22(2): 49-57.

18. Schwendicke F, Frencken JE, Bjørndal L, et al. Managing carious lesions: consensus recommendations on carious tissue removal. Adv Dent Res 2016; 22(2): 58-67.

19. Fontana M, Zero DT. Assessing patients caries risk. J Am Dent Assoc 2006; 137: 1231-9.

20. Lussi A, Imwinkelried S, Pitts NB, et al. Performance and reproducibility of a laser fluorescence system for detection of occlusal caries in vitro. Caries Research 1999; 33(4): 261-6.

21. Attrill DC, Ashley PF. Occlusal caries detection in primary teeth: A comparison of DIAGNOdent with conventional methods. British Dental Journal 2001; 190(8): 440-3.

22. Gomez J. Detection and diagnosis of the early caries lesion. BMC Oral Health 2015; 15(Suppl 1): S3.

23. Mohanraj M, Prabhu VR, Senthil R. Diagnostic methods for early de- 
tection of dental caries - A review. Int J Pedod Rehabil 2016; 1: 29-36.

24. Katge F, Wakpanjar M, Rusawat B, et al. Comparison of three diagnostic techniques for detecting occlusal dental caries in primary molars: An in vivo study. Indian J Dent Res 2016; 27: 174-7.

25. Zafersoy-Akarslan Z, Erten H, Uzun Ö, et al. Reproducibility and agreement of clinical diagnosis of occlusal caries using unaided visual examination and operating microscope. J Can Dent Assoc 2009; 75(6): 455 .
26. Sisodia N, Manjunath MK. Impact of low level magnification on incipient occlusal caries diagnosis and treatment decision making. Journal of Clinical and Diagnostic Research 2014; 8(8): ZC32ZC35.

27. Peker I, Alkurt M T, Bala O, et al. The efficiency of operating microscope compared with unaided visual examination, conventional and digital intraoral radiography for proximal caries detection. Int J Dent 2009; 2009: 986873.

\section{Применение современных увеличительных методов в диагностике окклюзионных кариозных поражений первых постоянных коренных зубов у детей}

Мая Рашкова, Ралица Боговска-Гигова, Христина Танкова, Наталия Гатева, Надежда Митова, Красимир Христов

Кафедра детской дентальной медицины, Факультет дентальной медицины, Медицинский университет - София, София, Болгария

Адрес для корреспонденции: Надежда Митова, Кафедра детской дентальной медицины, Факультет дентальной медицины, Медицинский университет - София, бул. „Георги Софийски“ № 1, 1431 София, Болгария; E-mail: nadia_bm@ab v.bg; Tel.: + 359886216886

Дата получения: 29 октября 2019 Дата приемки: 20 декабря 2019 Дата публикации: 30 сентября 2020

Образец цитирования: Rashkova M, Bogovska-Gigova R, Tankova H, Gateva N, Mitova N, Hristov K. Application of contemporary magnifying methods in the diagnostics of occlusal carious lesions on first permanent molars in children. Folia Med (Plovdiv) 2020;62(3):585-91. doi: 10.3897/folmed.62.e47751.

\section{Резюме}

Введение: Стоматологические операционные микроскопы (Dental operating microscopes (DOM)) позволяют стоматологам исследовать окклюзионную анатомию недавно прорезавшихся постоянных коренных зубов с помощью увеличения и фотографирования в клинических условиях и более точно идентифицировать все ранние кариозные поражения.

Цель: Установить преимущества увеличительной технологии при обнаружении ранних окклюзионных кариозных поражений недавно прорезавшихся постоянных первых коренных зубов.

Материалы и методы: Обследовано 176 первых моляров у 44 пациентов детского возраста, разделённых на две возрастные группы: 7-8 и 9-10 лет. Поверхности каждого зуба исследовали после тщательной очистки зубной щёткой без зубной пасты. Первоначально диагнозы устанавливались с использованием только освещения и клинического обследования. Они сопровождались визуальным осмотром окклюзионных поверхностей с использованием DOM (Semorr DOM 3000E) с увеличением $\times 8$. Окклюзионная поверхность была сфотографирована с помощью Nikon D5300 с соответствующим увеличением с целью фотодокументации.

Результаты: Это исследование показало, что стоматологические микроскопы увеличили частоту успешного выявления ранних кариозных поражений на окклюзионных поверхностях на 7\%. Наблюдалось также значительное увеличение числа диагностированных полостей дентина по сравнению с теми, которые были обнаружены невооружённым глазом. Использование DOM в детской стоматологии способствует более детальной и точной диагностике ранних кариозных поражений и / или кавитации трещин.

Заключение: Использование DOM способствует дифференцированному диагнозу между глубокими трещинами и начальными кариозными поражениями, что является ключевым моментом при оценке окклюзионных поверхностей недавно прорезавшихся постоянных коренных зубов, необходимому для их профилактической силанизации и микроинвазивного лечения.

\section{Ключевые слова}

стоматологический микроскоп, ранняя диагностика, окклюзионный кариес 